\title{
Mediating Athabascan Oral Traditions in Postsecondary Classrooms
}

\author{
Beth Leonard \\ University of Alaska Fairbanks \\ U. S. A.
}

This article describes how three versions of a Deg Hit'an Athabascan narrative are used in a pre-service teacher education course entitled "Alaska Native Education" at the University of Alaska Fairbanks. Use of both written and videotaped versions of this narrative, told by the late Belle Deacon, a Deg Hit'an storyteller formerly of Grayling, Alaska, facilitates students' understandings of the roles of oral traditions in educational processes for Alaska Native people. Students also gain an understanding of Athabascan worldviews; emphasized within these worldviews are the values of learning and honoring relationships as part of Athabascan educational processes.

Indigenous Education: Definitions and Processes Contexts of Oral Traditions: Challenges of Translation and Interpretation Narrative Summary of "Nił'oqay Ni'idaxin: The Man and Wife" Mediating Oral Tradition in Classroom Contexts Nił'ogay Ni'idaxin: The Man and Wife

The Old Man Who Came Down From Above the Second Layer of This World Conclusion Notes References

I am Deg Hit'an Athabascan from Shageluk, Alaska. In my current role as assistant professor at the University of Alaska Fairbanks (UAF) School of Education, I teach "Alaska Native Education," a semester-long (15 week) seniorlevel core course in the Elementary Education Program. Although UAF has one of the higher percentages of Alaska Native/Native American students in the United States (16\%), the majority of my students are not Alaska Native or Native American. Some of these students may choose to teach in an Alaska Native community in rural Alaska or will have Alaska Native students in their urban classrooms. For both Native and non-Native students, knowledge of Alaska Native educational paradigms and worldviews is critical for understanding why Western educational systems have impacted Alaska Native peoples and how these systems continue to influence Alaska Native education today. Also, with the current emphasis on the pedagogy of place educational models, it is vital for students to understand the challenges of presenting complex cultural materials in appropriate and respectful ways.

In this article, I describe how I use three versions of one Deg Hit'an Athabascan narrative in my course to build students' understandings of Alaska Native worldviews and educational processes. I begin by presenting contextual information related to the author and the Deg Hit'an cultural area. I then provide a 
paraphrased version of the narrative followed by an explanation of how I attempt to mediate its interpretation by providing additional contextual information through visual sources and explanations of two of the narrative titles. I conclude with comments on the importance of developing cross-cultural understandings of Alaska Native worldviews and broadening concepts of education and educational processes.

\section{Indigenous Education: Definitions and Processes}

There is a shared body of understanding among many Indigenous people that education is really about helping an individual find his or her face, which means finding out who you are, where you come from, and your unique character... Indigenous education is, in its truest form, about learning relationships in context (Cajete, 2000a, p. 183).

Topic areas in the "Alaska Native Education" course include examining the history of Western education for Alaska Natives and Native Americans, Alaska Native values and principles, and contemporary issues in indigenous education. I begin the course with an overview of Alaska Native/Native American educational contexts and worldviews, using readings by Vine Deloria, Jr. (Deloria \& Wildcat, 2001), Jeanne Eder (Reyhner \& Eder, 2004), Esther llutsik (1999), Angayuqaq Oscar Kawagley (Kawagley \& Barnhardt, 1999), and Paul Ongtooguk (2000). My primary goal for this topic area is to help students understand the complexity of oral traditions and their connections to traditional educational processes within Alaska Native contexts.

After examining how Western and Alaska Native educational systems differ in content, pedagogies, values, and goals, the students and I discuss the continuing roles of oral traditions within educational processes for Alaska Natives. According to Cajete (1994), the current educational system continues to disregard the fact that "myths, legends, and folk tales have been cornerstones of teaching in every culture" (p. 116). In the process of facilitating students' understandings of oral traditions and their connections to traditional educational processes, we begin to explore the worldviews of the Deg Hit'an and other Alaska Native people. As Cajete states in the quote above, this worldview guides educational processes that involve developing and maintaining relationships that extend well into, and far beyond, social realms.

To help illustrate Deg Hit'an Athabascan worldviews and educational processes, my students read a traditional creation narrative by the late Deg Hit'an elder Belle Deacon (1987c) entitled "The Old Man Who Came Down From Above the Second Layer of This World." Students also view a videotape of Deacon (1976) telling another version of the same narrative titled "The First Man and Woman." Prior to recording these English language versions, however, Deacon (1987b) recorded a version in Deg Xinag (the language of the Deg Hit'an) that she titled Nit'oqay Ni'idaxin translated as "The Man and Wife." The Deg Xinag version is also translated into English; however, many of the cultural 
concepts and worldviews, or "thick description" as described by Geertz (1973), remain concealed in the translated version as well as the English language versions where Deacon attempts to mediate for non-Deg Hit'an audiences. This mediation is evident in the three titles of Deacon's narrative listed in Table 1.

Table 1. Three Titles of Deacon's Narrative

1. Nit'oqay Ni'idaxin: The Man and Wife

2. The Old Man Who Came Down From Above the Second Layer of This World 3. The First Man and Woman

The first two narrative titles are examined in more detail in subsequent sections.

In the next section, I will present a brief description of the narrative or storytelling contexts. These contexts are extremely difficult to provide solely via narrative descriptions and may come across as one-dimensional for those not familiar with the complexity of Alaskan landscapes and cultures.

\section{Contexts of Oral Traditions: Challenges of Translation and Interpretation}

In my research with traditional Deg Hit'an narratives, I find that traditional narratives of Alaska Native people, as translated, often fail to articulate the relational and educational paradigms within Alaska Native cultures. Examination and explanation of these "deep structures" as referenced above is necessary to understanding Alaska Native methods of education and worldviews. As Lomawaima and McCarty (2006) note, "Translation is never a mechanical process of matching word to word. Translation is an intellectual and aesthetic challenge to reconcile unique concepts, transverse divergent ways of categorizing experiences, and illuminate the unfamiliar" (p. 104). In facilitating students' understandings of the cultural paradigms of the narrative "The Old Man Who Came Down From the Second Layer of This World," I present aspects of the Deg Xinag version, Nił'oqay Ni'idaxin, "The Man and Wife." This examination of both the English and Deg Xinag versions helps illustrate some of the worldviews and cultural paradigms that may not be apparent to an audience not familiar with Athabascan cultures nor fluent in the Deg Xinag language.

To help broaden the context of Deacon's narratives, students read the introduction to Engithidong Xugixudhoy: Their Stories of Long Ago (Deacon, 1987a), the volume containing the referenced narrative. This introduction includes a short biography of Deacon's family and a statement by Deacon that highlights the importance of listening, remembering, and individually reflecting on these narratives as part of the learning process: "Yixudz vighoyen'uxdhit. Agide yidong xinag yitołchiłdi dina'ididine' yidong... You should think about everything. Then you'll get the old wisdom that was told to us in the past" (Deacon, 1987a, pp. 2-3). In this statement, Deacon uses the term yidong xinag to refer to "the old 
wisdom." The word xinag, originally referred to earlier in this document as "language," takes on additional meanings when combined with the word yidong or "long ago": that is, "the old language," "the language of our ancestors," and notably, "the old wisdom." One could argue that speakers may also use the term xinag to refer to the vast stores of knowledge used to educate succeeding generations via the power of breath in oral traditions. ${ }^{1}$

In addition to what the students read prior to the viewing the videotape, I also show photographs of the Deg Hit'an area via a PowerPoint presentation and explain my connections to the Deacon family. These value systems that acknowledge and honor relationships and connections, as Cajete notes above, remain an integral part of educational paradigms for Alaska Native and other indigenous peoples. Pre-service teachers, especially those who are considering teaching positions in Alaska Native communities, should have at least an elementary understanding of Alaska Native value systems, cultural connections, and relationships in order to effectively communicate with students and their families.

All of the narratives in Deacon's book were recorded in her home in Grayling, Alaska, an Athabascan community on the Yukon River in interior Alaska. The recordings also capture household sounds including knocking as visitors come by, Deacon's little dog barking, her husband John talking, and the kitchen clock ticking. My parents and I visited the home of John and Belle Deacon on many occasions, so listening to these recordings is like a trip back in time to those visits in the late 1960s and early 1970s. These background noises do not distract from the story but instead add to the context and overall appeal of the audio versions, effectively bringing the past into the present for those of us who knew John and Belle Deacon.

Figure 1. Alaska Native Languages

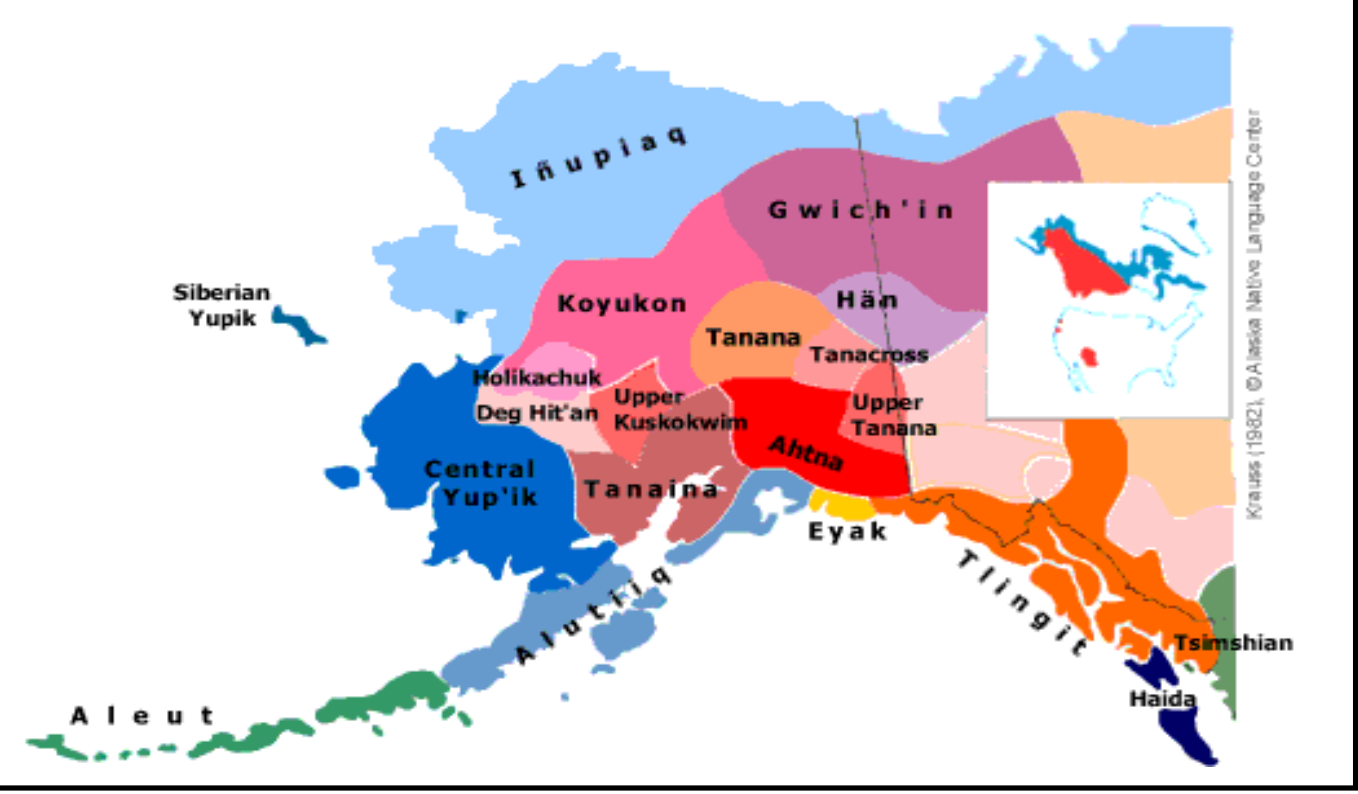


The Deg Hit'an area includes the villages of Anvik, Grayling, Holy Cross, and Shageluk. Grayling is located within the Holikachuk language area; however, several Deg Xinag speakers reside there as well. The Deg Hit'an area is the westernmost cultural area within the Athabascan region that stretches from Holy Cross, Alaska, to Hudson Bay in Canada as illustrated by the Alaska Native Peoples and Languages Map (Krauss, 1982) in Figure 1.

Anvik, Grayling and Holy Cross are located on the lower-middle Yukon, while Shageluk is on the Innoko River, a Yukon River tributary. Holy Cross is considered part of the Deg Hit'an area but borders the Yup'ik area and is currently a mixed Athabascan-Yup'ik community. Many Grayling residents are originally from Holikachuk, an Innoko River village above Shageluk that was abandoned in 1963. During the pre-European contact period, and for some time post-contact, most residents did not live year-round in one location; rather they moved among summer, winter, and spring camps located on the Innoko or Yukon Rivers. I use the following personal photos ${ }^{2}$ of the Innoko River and Shageluk (Figures 2 and 3) in my PowerPoint presentation so students have some concept of the physical landscape within this region.

The process of at least partially contextualizing this Deg Hit'an narrative through Deacon's video and my personal photos is integral to developing a cursory understanding of these narratives. Many Alaska Native narratives clearly articulate the connections between the people and the land they have occupied for thousands of years. These connections to place are often difficult to convey to students not familiar with Alaska Native cultures, as the class meets in an extremely decontextualized university setting.

Figure 2. Innoko River below Shageluk, Alaska

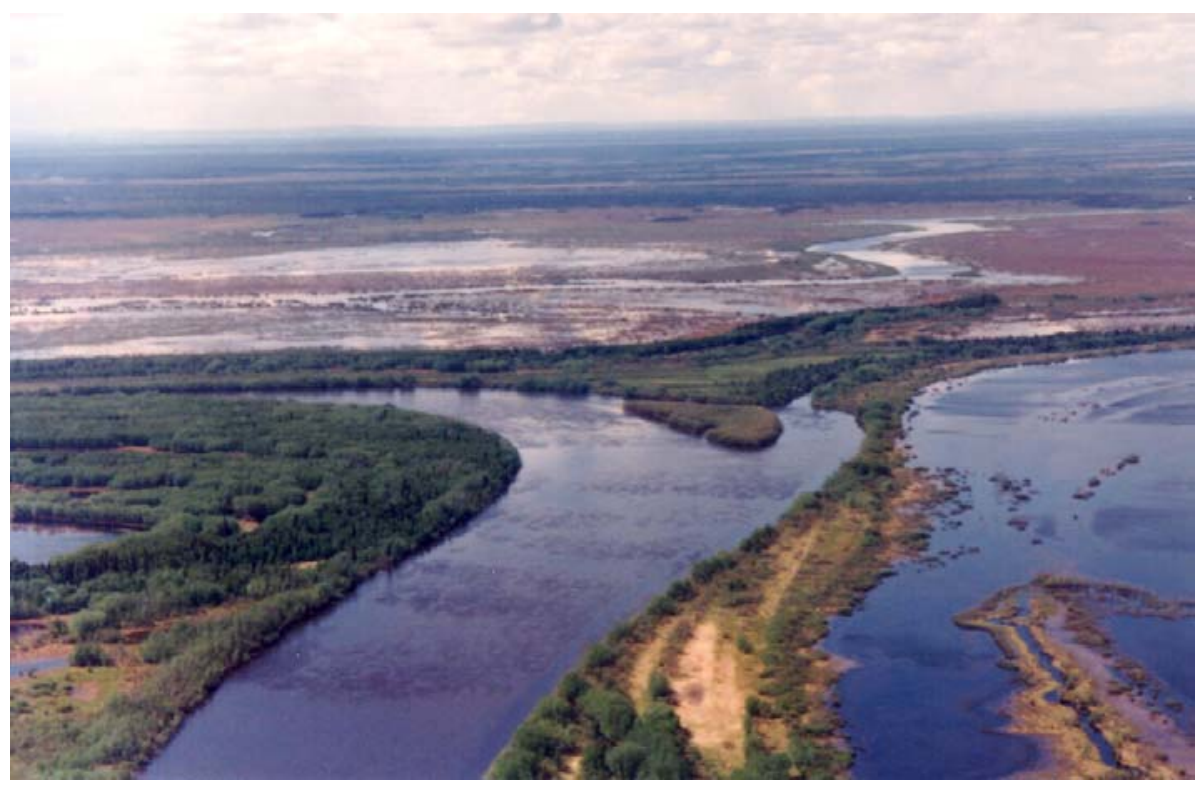




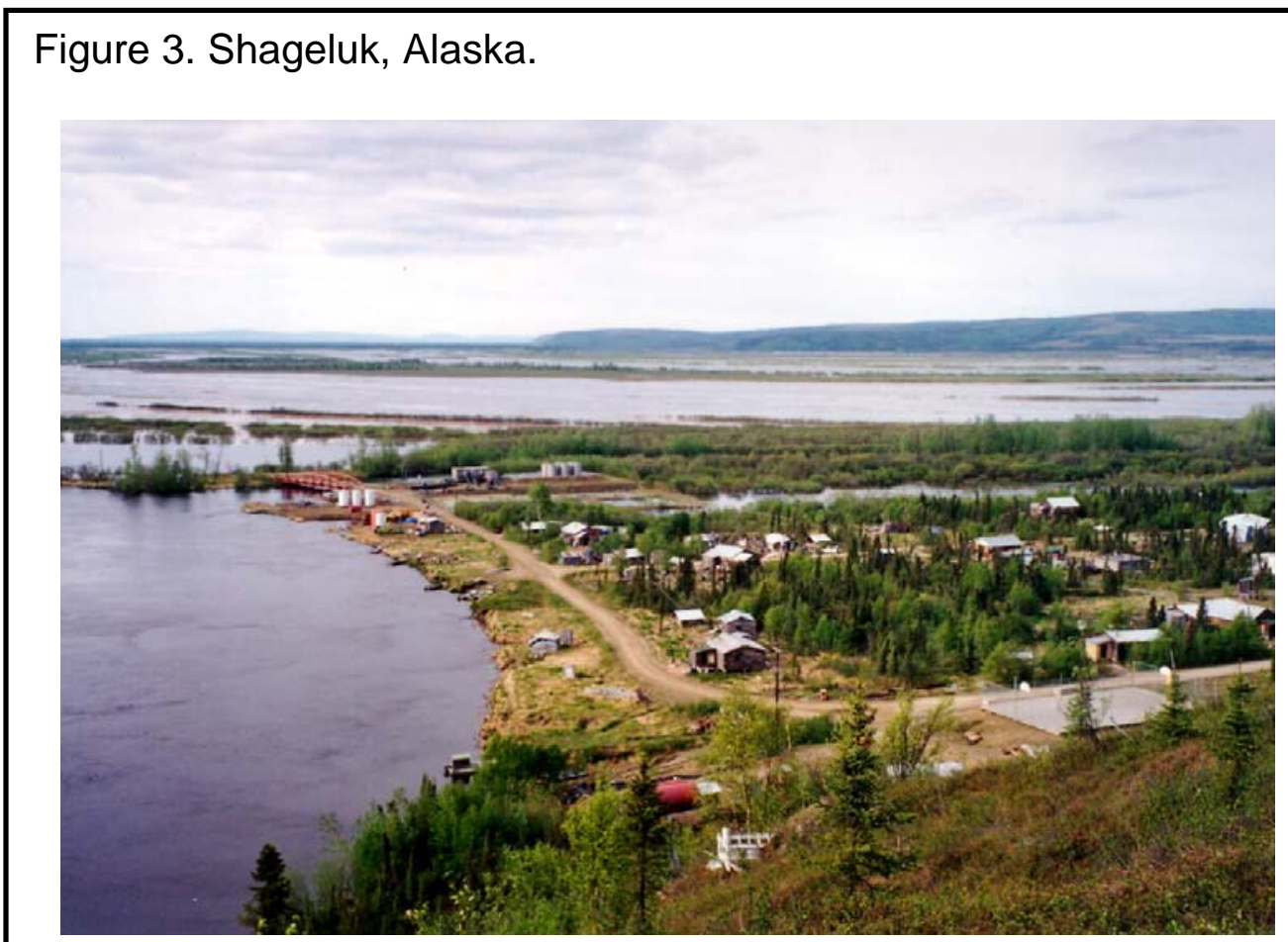

The following is an extremely condensed, paraphrased version of Deacon's narrative; both the audiotaped and videotaped versions are quite long at over 40 minutes in length.

\section{Narrative Summary of "Nił'oqay Ni'idaxin: The Man and Wife"}

Deacon (1987b) begins her narrative by identifying a couple who lived by themselves at the mouth of a side stream or slough. The man spent a great deal of time trapping, while the wife stayed at home chopping wood, sewing, and cooking for her husband. The wife always made "ice cream" for her husband, and after he ate his main meal he specifically asked for this dish (the contents and process of making "ice cream" are explained in the next section). As the man continued to go out hunting and trapping for days at a time, his wife began to feel lonesome. This cycle of the same activities goes on for a number of years, with the wife regularly mixing ice cream for her husband. One day during the fall season she does not feel well and does not make the ice cream for him. The man urged his wife to make the ice cream as he did not feel full without it and only slept well after eating ice cream. His wife then went outside for snow to make ice cream and did not return. The man searched for her and found the bowl and spoon she had taken with her but found no tracks beyond the water hole. He mourned for her during the subsequent fall and winter, becoming thin and weak and thought that he might die. 
At mid-winter an old man, whom the husband later learns is Raven, visited him and told the husband that his wife was stolen by a giant and taken to "a land deep down in the water" (p. 15). Raven told the man that he would not be able to get his wife back without his (Raven's) help. After the old man ate and rested, they began cutting down a large spruce tree with a stone axe. They then limbed the tree and cut the top off, making it about "twelve arm spans long" (p. 19). The spruce was then carved into the shape of a pike, with the insides and mouth hollowed out. After the pike was complete, they tied a rope to it and dragged it to the water hole. Raven told the man to chop a hole in the waterhole big enough to accommodate the fish and to fetch other items for his journey. These items included birch punk, a clay lamp to provide light for the man while inside the fish, and weasel skins to provide a disguise once he reached the underwater village. Raven then "blew with his hands and made medicine with a song" (p. 24). He hit the fish on the back and it sank to the bottom of the river while producing a humming noise that shook the man.

After reaching the underwater village with a "big kashim and many winter houses" (p. 25) the man rescued his wife from the giant, and he and his wife returned to their home. Raven then instructed the fish to "stay in a place where there are lakes, where no one will go," and told the fish, "For people who step there on the ice of the lake, you will shake your little tail" indicating "someone's impending death." The fish then returned "to the bottom"; however, they (the man and wife) "don't know where" (p. 31).

After their return the wife began to make ice cream, and she and her husband dressed in new clothes. The wife planned to give Raven the ice cream and some cooked game; however, Raven told the man and wife, "I am Raven from the upperworld. I don't eat this food. I live only on food that is placed in the

Figure 4. Great Northern Pike

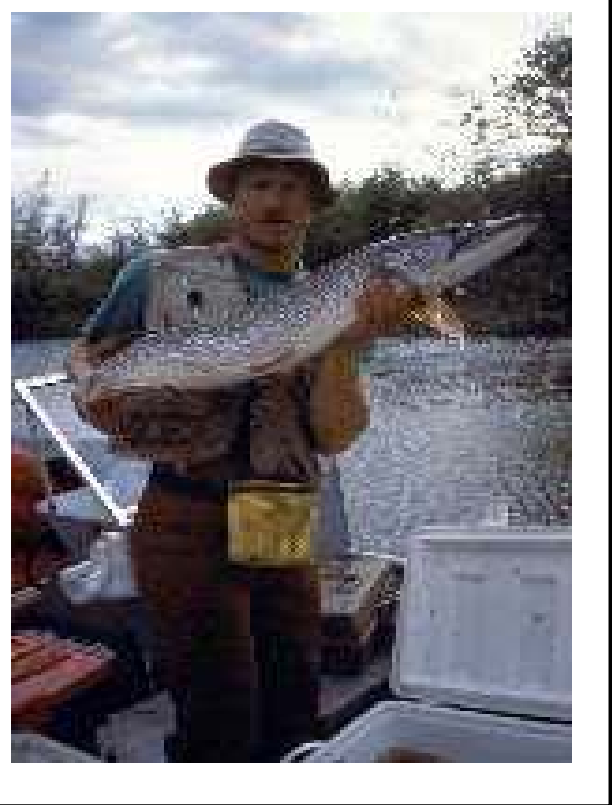
fire" (p. 31) and said that he would stay with them one more night, leaving at the first light of the next morning. Raven then instructed them to build a fire and burn first the food, then the bedding he used while staying with the man and wife, and lastly the new clothes. Raven then "floated upward" and "disappeared behind the clouds up in the other world" (p. 33). Deacon ended the story with "Idixunili'on'," literally, "That is as far as the story goes" (p. 33).

\section{Mediating Oral Traditions in the Classroom Contexts}

In presenting these narrative versions, there are usually a number of terms and concepts unfamiliar to non-Native 
students; these may include "Raven," "ice cream," "pike," "weasel" (ermine), "punk," and "kashim." In the PowerPoint presentation referenced earlier, I include photos of the great northern pike (Figure 4), weasel or ermine, punk (a fungal growth often burned as a mosquito repellant), a modern version of Grayling's "kashim" or community hall, and the Shageluk mask dancers performing the "Crow (Raven) Dance." Students understand that the creation of the pike is a central theme within the narrative. However, because of the limitations of the translated versions, students need additional contextual information to understand the connections between the Deg Hit'an people and the pike; these connections began with the creation of the pike and extend into the present. For the Deg Hit'an people, pike or "jackfish" are an important part of the traditional subsistence ${ }^{4}$ cycle as they are abundant in the region and can be harvested year-round from lakes, side streams, and rivers. Pike are an ancient, aggressive, and predatory fish and can grow up to six feet in length and 50 pounds in weight (Nelson, 1983, pp. 72-73).

Pike is usually served boiled, roasted, or fried; the meat can also be used to make vanhgiq or "ice cream," a significant food staple and a central theme within Deacon's narrative. Deacon refers to several types of ice cream in her narratives, including those made with fish, caribou or moose fat, or snow. Pike is one of the fish used to make fish ice cream, as the meat flakes well and is readily available at most times of the year, although other white fish are used as well. The process of making fish ice cream or vanhgiq is extremely time-intensive. Vanhgiq is made by combining fat (fish oil, or more recently, hydrogenated vegetable oil) with the boiled meat of the fish. After the fish is boiled, the skin is removed and the meat de-boned. The liquid is then squeezed out of the fish meat by hand until it becomes dry and powdery. The fish meat and fat are combined and whipped, using one hand, until light and fluffy. Sugar, berries, and sometimes milk or a sweetened cream mixture are then added to finish the dish. Blueberries, lowbush cranberries, crowberries, and/or salmonberries seem to be the most popular fruit to add to the ice cream currently. Today the Deg Hit'an people continue to serve vanhgiq in large quantities at potlatches, mask dances, funeral, and memorial feasts. The connections among the pike, vanhgiq, and funeral feasts are further reinforced in the subsequent section that discusses the Deg Hit'an universe.

As one of the main characters, "Raven" also warrants further explanation. The Deg Xinag term for "Raven" literally means "your (plural) grandfather" or "you guys' grandfather." These connections are further emphasized in the "Man and Wife" version as Raven calls the husband and wife "sitthey," literally "my grandchildren." In the Deg Hit'an culture and other Alaska Native cultures, Raven (or "Crow") often plays a central role as a creator, also a "trickster" or character who initiates change. In this narrative, Raven creates and animates the pike but also functions as an educator to help the husband and wife understand their place in the world and the proper protocols for dealing with "Raven" and those who reside in other "levels" of the Deg Hit'an universe. These levels and protocols are explained in a subsequent section as I examine the narrative titles. 
Finally, I address the term "kashim" as both a physical building and educational construct. Traditionally, men of the community lived in the kashim, so this building was, in essence, one of the educational centers for the younger men and boys in the community. This building was part of the place-based educational system where young people learned the necessary skills in order to survive and flourish in this area. The kashim was also used for various ceremonies including the mask dances, funeral, and memorial feasts; today these ceremonies are still held in the kashim so this place continues to function as a community educational center.

In the next two sections, I briefly examine two of the narrative titles: Nit'oqay Ni'idaxin ("The Man and Wife") and "The Old Man Who Came Down From Above the Second Layer of This World."

\section{Nit'oqay Ni'idaxin: The Man and Wife}

As stated previously, the term nit'oqay ni'idaxin is translated as "the man and wife." A morphological ${ }^{5}$ examination of this title reveals the reflexive prefix nit-, meaning "with each other" used to mark vital, reciprocal social relationships. The affix -'o is a contracted form of the stem for "wife," that is, -'ot (unpossessed form), and the final segment -qay indicates "multiple persons" or can stand alone as the word for "village." Other reflexive terms from the Deg Xinag Noun Dictionary (Kari, 1978)are listed below:

Table 2. Deg Xinag Reflexive Kinship Terms

\begin{tabular}{|l|l|l|}
\hline Xinag & $\begin{array}{c}\text { English } \\
\text { Translation }\end{array}$ & \multicolumn{1}{c|}{ Comments } \\
\hline Nitngonhye & Mother and Child & ngonh - "your mother" \\
\hline Nitto'ye & Father and Son & -to - unpossessed stem for "father" \\
\hline Nitq'uye & Aunt and Niece & $\begin{array}{l}-q \text { 'u - unpossessed stem for "aunt" } \\
\text { (mother's sister) }\end{array}$ \\
\hline Nitqing'qay & Husband and Wife & -qing'- unpossessed stem for "husband" \\
\hline
\end{tabular}

In his analysis of similar Koyukon ${ }^{6}$ narratives, Thompson (1990) observes that many of these:

... begin with the phrase "Neetkkun kkaa łedo." "A man and wife were living together".... In such forms, the older or most important member of the pair is the only one explicitly stated.... If a story begins with this phrase, one can assume that the couple will be broken up by either abduction or infidelity. (pp. 100-101)

The Koyukon term used in this example, "neełkkun kkaa" (cognate to the Deg Xinag term nitqing'qay above) indicates that the husband or man is the 
"older or more important member of the pair." Deacon's use of the term "nił'oqay" in her title puts the emphasis on the woman or wife, indicating her importance in this creation story.

However, the meaning of ni'idaxin is not explained in the translation. In examining the morphology of the word, the prefix ni- may refer to something specific in the environment. The areal prefix $x i$ - indicates something within the wider environment. Athabascanist James Kari (personal communication, 2007) notes that the verb theme -dax in this example means "plural events occur," or "experience plural events." The final portion of the word -in can be translated as "those who" are in a position or constant state.

Table 3. Nił'oqay Ni'idaxin: Morphological Analysis

\begin{tabular}{|l|l|l|}
\hline Deg Xinag & $\begin{array}{l}\text { English } \\
\text { Translation }\end{array}$ & \multicolumn{1}{|c|}{ Morphological Analysis } \\
\hline Nit'oqay & $\begin{array}{l}\text { The Man and } \\
\text { Wife }\end{array}$ & $\begin{array}{l}\text { nił- reciprocal prefix } \\
\text { o-contracted form of kinship term 'wife' } \\
\text { qay-plural P. (person) }\end{array}$ \\
Ni'idaxin & $\begin{array}{l}n i- \\
\text { 'idax -plural events occur, experience plural events } \\
\text { in - "those who" (are in a position or constant state) }\end{array}$ \\
\hline
\end{tabular}

The previous analysis illustrates the kinds of complex cultural information that remains veiled at the conclusion of the original translation process. These concepts are also not obvious from the English translations. This example illustrates the structural aspects of the language that emphasize the reciprocal relationship between the man and his wife, and their connections to a specific place through time. ${ }^{?}$

\section{The Old Man Who Came Down From Above the Second Layer of This World}

As noted in previous sections, my students read Deacon's English version of the narrative "The Old Man Who Came Down From Above the Second Layer of This World." Deacon's use of the word "man" in her English title and text differs from the translation of the Deg Xinag version. In the translated Deg Xinag title "The Man and Wife," the term "man" is used to identify the husband in a reciprocal relationship with his wife as noted above. Also, in the Deg Xinag version, Deacon uses the term Yixgitsity or "Raven" to refer to the character that comes to aid the husband. In her English version, Deacon does not use the term 
"Raven" at all; rather, she refers to Raven's character as the "Man" or "Old Man" throughout the narrative.

To explain what Deacon means by "the second layer of this world" in the next section, I refer to sources by Cornelius Osgood $(1958,1959)$, a Yale anthropologist who completed an extensive ethnography of the Deg Hit'an.

\section{Four Levels of the Deg Hit'an Universe}

Osgood's (1959) discussion of Deg Hit'an spiritual beliefs includes a section titled "The Universe and Determinate Things" in which he talks about the concept of a four-level universe (pp. 103-106). The first level is "the apparent world of normal living things." According to Osgood, the yeg, or "spirits that have departed from their partner bodies," inhabit the other levels; however, the shaman's yeg can continue to exist on the first level.

Most departed spirits reside on the second level known as "Raven living," "which is slightly below the surface of the apparent world." Osgood reiterates a story of how this level was created by Raven during the time when "the animals and man still spoke a common language" and people did not die as they do today; as Osgood describes it, "actually, there was no place to go." Raven married "a fine-looking young woman" but later became captivated with her mother and sought to find a way to live with her. Raven then began digging a hole, "finally coming out on a bank of a faraway river," a project that took two years. After building two summer houses on two adjacent points of land, he then returned to his village and "hoped that his mother-in-law would become sick" as "the world was already too crowded with people." His mother-in-law did sicken and stopped eating. Raven then led her into the tunnel he had made and they spent four nights on this journey.

The third level is called "up on top of the sky." Osgood describes this as "a good place but little is actually known about it." This level has "a very large lake with very large fish in it" and accommodates the yeg of people "who have frozen to death, who have been killed in war or murdered, who have died in childbirth, or who have committed suicide (except for those who drown themselves)."

The fourth level and lowest level is called "fish trail" and holds yeg of people "who have drowned, either accidentally or by intention... There they have a village which is neighboring to the several villages occupied by different species of salmon." The yeg that inhabit this level can go up "through a hole in order to visit their friends in "Raven's living."

Funeral and memorial ceremonies held today still reflect the values and protocols taught by Raven in this narrative. Funerals or potlatches for the dead last four days; this is also noted by Osgood $(1958$, p. 275). Prior to sealing the casket, four candles are placed in each corner of the casket to provide light during the night during the four-night journey to the afterlife. The following quote 
by the late Hannah Maillelle of Grayling, Alaska, describes "last rites" of stamping the feet four times, observed prior to the closing and nailing of the coffin lid:

At a funeral people stamp their feet four times the last thing when the coffin is still open, before they close it. They lift the person's spirit up so they don't bury the spirit with them. It's a spirit sending. There's always somebody there by the coffin that's supposed to be lifting the spirit up. You just tell the person "Diggi ts'in'!," "up" in Native. If you don't do that they hang around all the time. But if you do that, they go up. (Maillelle, 2002)

The husband and wife are highly proficient in a number of subsistence activities, however are still learning about their place or level wherein they appear to be the only humans. The relationship they develop with Raven or the Old Man over the course of time teaches them the importance of reciprocal gifting (through burning) of food and clothing to Raven and others who inhabit the other levels. In "The Old Man Who Came Down From Above the Second Layer of This World," the Old Man (Raven) states:

But all that food which you put away for me - ice cream, things - you make big fire on the bank tomorrow morning. You burn the FOOD first. Then you put my bundle, my blanket, and BURN it up. And those boots, parka, mittens, cap, everything, bundle it up and burn it too. And it'll come down to ashes. And then you'll see me get out of sight. And it will be, when I get back to my place up there, it will be there just brand new; I'll put it on (Deacon, 1987c, p. 40).

The ongoing nature of social relationships and obligations to those that have died and journeyed to another level continue to be recognized today, highlighting the resilience of these beliefs and practices despite opposition by missionaries and educators. Relatives of the deceased burn selected pieces of clothing prior to the burial and burn small portions of food at each community meal during the four-day ceremony.

\section{Conclusion}

In addition to the narrative titles explained in this paper, there are a number of other connections within this narrative that my students and I examine during the topic area on traditional education. In a forthcoming publication, the "Alaska Native Reader" (Leonard, in press), I discuss some of these aspects including an overview of Athabascan narrative genres, epistemological and ontological aspects of the "pike," definitions of "subsistence," and values inherent in Athabascan subsistence practices. My experiences with Deacon's narratives in many ways parallel those of my students who are not familiar with Deg Hit'an culture. Because I am not fluent in the Deg Xinag language, this limits my understanding of Deacon's narratives, although I grew up surrounded by the culture of the Deg Hit'an people. Many of the practices described by Osgood and other anthropologists remain central in Deg Hit'an communities, despite 
opposition by early missionaries and educators as noted previously. Currently, however, education about these beliefs and practices varies among families and communities within this area.

In his book Keeping Slug Woman Alive, Pomo/Miwok scholar Greg Sarris (1993) discusses Bateson's notions of "culture contact" (p. 43), that is cultures come into contact both cross-culturally as well as interculturally. My research is in many respects a cross-cultural, inter-cultural, and somewhat decontextualized endeavor considering my background, a background that resulted in my initial experience with oral traditions in written formats, then secondarily through listening to audio recordings. I am careful not to classify myself as an "expert" on the Deg Hit'an culture as I am a cultural insider in some ways; however, in other ways I remain a cultural outsider, as noted above.

Stories, or mythology, according to Cajete (2000b) "are alternative ways of understanding relationships, creation, and the creative process itself...how humans obtain knowledge, how they learn responsibility for such knowledge, and then how knowledge is applied in the proper context" (p. 44). These mythologies contain "expressions of a worldview in coded form..." (p. 62). Through examining Deacon's narratives in English and Deg Xinag, my students begin to understand the complexities of oral narratives in translation, respect worldviews that emphasize connections that extend well into and far beyond social realms, and reconstruct narrow concepts of education and educational processes. For teachers who serve Alaska Native students, knowledge of the contexts of education (both historical and contemporary), worldviews, and value systems remain vital to establishing and maintaining respectful communication with students, their families, and communities.

\section{Notes}

1. See sources by the late Chief Peter John (Krupa, 1996), N. Scott Momaday (1997), and Ofelia Zepeda (1995) that provide explanations of the "power of breath" within oral traditions.

2. Photos of Deacon's home community, Grayling, approximately 30 miles overland from Shageluk are available via the Iditarod Area School District website: http://kgx.schoolaccess.net/.

3. Public domain photo from U.S. Fish \& Wildlife Service Digital Library System was retrieved on May 23, 2008, from http://images.fws.gov/default. cfm?fuseaction=records. display \&CFID $=357997 \&$ CFTOKEN=93245000\&id $=5$ C7EA00D-1143-3066-4085A76079B10CC3.

4. Subsistence is a term widely used and, for the most part, narrowly understood, especially in contemporary political contexts when referring to the hunting and fishing practices and rights of indigenous peoples. For most of Alaska's non-indigenous residents, non-Native politicians in particular, the terms "subsistence" or "subsistence lifestyle" are rarely explored or 
understood beyond superficial levels. Shallowly defined, subsistence seems to indicate a general knowledge of how to live off the land or "subsist" on what the land has to offer in terms of hunting, fishing, and trapping." For indigenous peoples, these limited definitions disconnect practices, or lived experiences, from spiritual dimensions. For more detailed explanations of subsistence worldviews, see publications by Yup'ik scholar Oscar Kawagley (1995; 1998 with Norris-Tull \& Norris-Tull), Koyukon cultural anthropologist Miranda Wright (1995), Vine Deloria, Jr. (1994), Ellen Bielawski (1990, 1996), Robin Ridington (1990), Richard Nelson (1983), Martha Johnson (1992), and Peter Knudtson and David Suzuki (1992).

5. Students accepted into the elementary education program are required to take "Language, Linguistics, and Education," a linguistics course geared toward educators versus linguistics majors. By the time students enroll in "Alaska Native Education" during their junior or senior year, most have completed this course and are familiar with terms used in linguistics such as morphology, phonology, syntax, semantics, semiotics, and affixes.

6. The Deg Hit'an and Koyukon Athabascan cultural regions share many similar beliefs and practices.

7. It should be noted that Kari and Deacon did discuss titles to each narrative prior to publication, and Deacon chose the English title "The Man and Wife." Kari's translation of the term nił'oqay ni'idaxin is "the man and wife are living, spending their lives" (2007, personal communication).

\section{References}

Leonard, B. (in press). Deg Xinag oral traditions. In M. Williams (Ed.). The Alaska Native reader: History, culture, politics. Durham, NC: Duke University Press.

Bielawski, E. (1990, August). Cross-cultural epistemology: Cultural readaptation through the pursuit of knowledge. Paper presented at the $7^{\text {th }}$ Inuit Studies Conference, University of Alaska Fairbanks.

Bielawski. E. (1996). Inuit indigenous knowledge and science in the Arctic. In L. Nader (Ed.), Naked science: Anthropological inquiry into boundaries, power, and knowledge (pp. 216-227). New York: Routledge.

Cajete, G. (1994). Look to the Mountain: An Ecology of Indigenous Education. Durango, CO: Kivaki Press.

Cajete, G. (2000a). Indigenous knowledge: The Pueblo metaphor of indigenous education. In M. Battiste (Ed.), Reclaiming indigenous voice and vision (pp. 181-191). Vancouver, BC: UBC Press.

Cajete, G. (2000b). Native science: Natural laws of interdependence. Santa Fe, NM: Clear Light Publishers. 
Deacon, B. (1976). The first man and woman. On The Anchorage Historical and Fine Arts Museum Exhibit and Lecture Series - Athabascans: Strangers of the North [Videotape]. Anchorage, AK: University of Alaska Media Services: Alaska Native Cultural Heritage and Information Bank.

Deacon, B. (1987a). Engithidong xugixudhoy: Their stories of long ago. Fairbanks, AK: Alaska Native Language Center.

Deacon, B. (1987b). Nifoqay ni'idaxin: The man and wife. In Engithidong xugixudhoy: Their stories of long ago (pp. 5-33). Fairbanks, AK: Alaska Native Language Center.

Deacon, B. (1987c). The old man who came down from above the second layer of this world. In Engithidong xugixudhoy: Their stories of long ago (pp. 3440). Fairbanks, AK: Alaska Native Language Center.

Deloria, Jr., V. (1994). God is red: A native view of religion ( $2^{\text {nd }}$ ed.). Golden, CO: Fulcrum Publishing.

Deloria, Jr., V., \& Wildcat, D. R. (2001). Power and place: Indian education in America. Golden, CO: Fulcrum Resources.

Geertz, C. (1973). The interpretation of cultures. New York: HarperCollins.

Ilutsik, E. (1999). Traditional Yup'ik knowledge: Lessons for all of us. Sharing Our Pathways: A newsletter of the Alaska Rural Systemic Initiative, 4(4), 1, 811.

Johnson, M. (1992). Lore: Capturing traditional environmental knowledge. Hay River, NWT, Canada: Dene Cultural Institute.

Kari, J. (1978). Deg Xinag: Ingalik noun dictionary (preliminary). Fairbanks, AK: Alaska Native Language Center.

Kawagley, A. O. (1995). A Yupiaq worldview: A pathway to ecology and spirit. Prospect Heights, IL: Waveland Press.

Kawagley, A. O., \& Barnhardt, R. (1999). Education indigenous to place: Western science meets native reality. In G. A. Smith \& D. R. Williams (Eds.), Ecological education in action: On weaving education, culture, and the environment (pp. 117-140). State University of New York Press.

Kawagley, A. O., Norris-Tull, D., \& Norris-Tull, R. A. (1998). The indigenous worldview of Yupiaq culture: Its scientific nature and relevance to the practice and teaching of science. Journal of Research in Science Teaching, 35(2), 133-144.

Knudtson, P., \& Suzuki, D. (1992). Wisdom of the elders. Toronto: Stoddart Publishing.

Krauss, M. (1982). Map: Native peoples and languages of Alaska. Fairbanks, AK: Alaska Native Language Center.

Krupa, D. J. (Ed.). (1996). The gospel according to Peter John. Fairbanks, AK: Alaska Native Knowledge Network. 
Lomawaima, K. T., \& McCarty, T. L. (2006). To remain an Indian: Lessons in democracy from a century of Native American education. New York: Teacher's College Press.

Maillelle, H. (2002). Gan tr'idighine': What we said (2/26/2002). Deg Xiqi Xinatr'iditlghusr: Conversational Deg Xinag. Retrieved June 28, 2006 from http://www.alaskool.org/language/Athabaskan/Deg Xinag/ClassSpring200 2/summary $0226 \quad 02 . \mathrm{htm}$

Momaday, N. S. (1997). The man made of words. New York: St. Martin's Press.

Nelson, R. K. (1983). Make prayers to the raven: A Koyukon view of the northern forest. University of Chicago Press.

Ongtooguk, P. (2000). Aspects of traditional Inupiat education. Sharing Our Pathways: A newsletter of the Alaska Rural Systemic Initiative, 5(4), 8-12.

Osgood, C. (1958). Ingalik social culture (Vol. 53). New Haven, CT: Yale University Press.

Osgood, C. (1959). Ingalik mental culture (Vol. 56). New Haven, CT: Yale University Press.

Reyhner, J., \& Eder, J. (2004). American Indian education: A History. Norman, OK: University of Oklahoma Press.

Ridington, R. (1990). Little bit know something. lowa City, IA: University of lowa.

Sarris, G. (1993). Keeping slug woman alive: A holistic approach to American Indian texts. Berkeley, CA: University of California Press.

Thompson, C. (1990). K'etetaalkaanee: The one who paddled among the people and the animals: An analytical companion volume ( $4^{\text {th }}$ ed.). Fairbanks, AK: Alaska Native Language Center.

Wright, M. H. (1995). The last great Indian war (Nulato 1851). Unpublished M.A. thesis, University of Alaska Fairbanks: Department of Anthropology.

Zepeda, O. (1995). The continuum of literacy in American Indian communities. The Bilingual Research Journal, 19(1), 5-15. 